NORDISK MUSEOLOGI $1997 \cdot 2$, S. 3-12

\title{
Med GutenberG PÅ INTERNETTET
}

\author{
Arno Victor Nielsen
}

I midten af 1400-tallet opfandt Johan Gutenberg bogtrykkerkunsten, også kaldet «den sorte kunst». Siden fulgte sattemaskinen, hurtigpressen, rotationspressen, skrivemaskinen, analfabetismen, retskrivningsordbogen, sprognavnet og pausekommaet. Nu tager de elektroniske medier over og bogen og papirtrykket bliver erstattet af billedskarmen. Den udvikling skrammer mange, men vi glemmer at $i$ skriftens lange historie er bogens ara bare en parentes. Ordene blev sparret inde og stillet op på rakke og geled $i$ bogens fengsel. Nu er de sluppet fri, og multimedier og hypermedier lover en revolution $i$ kommunikations- og tankeformerne.

Engang gjaldt den regel, at en nyt medium altid indeholdt det gamle som sit indhold. Således indholdt skriften talen, bogen skriften, filmen romanen. Men cdrommen indeholder samtlige andre medier i sig: bog, film, tv, billede etc.

\section{SKRIFTKULTUREN BESEJRER DEN MUNDTLIGE KULTUR}

Bøger kan købes, læses og samles. Og så kan de brændes. Da nazisterne brændte bøger den 10. maj 1933 var det ikke første gang der blev arbejdet $\mathrm{i}$ åndens krematorium. Alligevel står den nationalsocialistiske bogbrænding som en påmindelse om det barbari der hvert øjeblik truer den oplyste menneskehed. Det er så at sige oplysningen selv der her slår ud i lys lue. Hvor ofte er vi ikke på TV og i aviser blevet præsen- teret for billeder af Sarajevos udbrændte og udbombede bibliotek?

En mere nutidig, men til gengæld ikke sand beskrivelse af en bogbrænding finder vi hos Umberto Eco i romanen Rosens Navn. I Umberto Ecos bestseller brændes der bøger, ja et helt bibliotek. Men her tager fortælleren parti for mordbrænderen ud fra den opfattelse at bøger og biblioteker er en tvivlsom gave til menneskeheden. Hele den verdslige ordensmagt hviler nemlig på skriftkulturen og bogen.

Når skriften selvstændiggør sig i forhold til stemmen, når den mundtlige kultur desavoueres og trænges i baggrunden af skriftkulturen, bliver folket adskilt fra eliten. Det er bogen som skaber folket. Grundtvig har for så vidt ret $\mathrm{i}$ at folket holdes i live af det talte ord. Han bytter bare om på årsag og virkning. Det er fordi 
4 de er udelukket fra skriftkulturen, fra magtens sprog, at de er henvist til den mundtlige kultur; men af mangel på pleje er denne kultur degenereret. Det var den alfabetiske skrift i kombination med bogtrykkerkunsten, som dræbte mundtligheden, erstattede ørenvidnet med øjenvidnet og lod sandheden fremstå sort på hvidt.

\section{BOGEN OG BIBLIOTEKETS METAFYSIK}

Biblioteker såvel som bøger er indhegninger, som monopoliserer viden og hukommelse. Engang var der jernbeslag på de gamle bogbind, så kunne man sætte en lås $\mathrm{i}$ bogen. Men selv uden lås kan det være svært at trænge ind $\mathrm{i}$ en bog. Mange døre skal åbnes før man når frem til skatten. Først er der titelsiden, så er der udgiverens anmærkninger, så følger et forord, dernæst eventuelle tilegnelser, endelig er der indledningen. Man slipper heller ikke uden videre ud igen. Først er der slutkapitlet, som afrunder og præsenterer læseren for det olympiske tilbageblik. Så følger efterskrift og eventuelle noter og indeks. Som man kan forstå rummer bogen et helt metafysisk verdensbillede, en verden som begynder, spreder sig og samler sig til en smuk afrundet helhed. Og ligesom verden efter nogens mening må have en skaber, har bøger en forfatter. Bøger har en begyndelse, en midte og en slutning og ligner dermed det billede af verden som har behersket menneskenes forestillinger i årtusinder, nemlig verden som et lukket rum, hvor alt er orienteret ud fra et helligt centrum. Når virkeligheden fremstilles i en bog tager den sig derfor som oftest ganske tilforladelig og overskuelig ud. Derfor nægter vi at give slip på bogen.
Men bogen lever ikke op til kompleksiteten i vore sociale systemer.

Bogen er meget mere end en fysisk ting, som man i mange tilfælde kan have i lommen, og som man læser ord efter ord $i$ en lineær sekvens fra side et til slutningen. Teksten er ikke bare fanget i bogens materialitet. Den er også bundet til papiret, kartonet, farvestoffet og er forbundet med de økonomiske og historiske forhold, som den er blevet produceret og distribueret under. Den er måske fundet værdig til at indgå i en serie. Den kan være udsolgt, og dens første oplag kan være blevet et samlerobjekt.

\section{FRA ARS MEMORIAE TIL HUKOMMELSESMASKINE}

Jonathan Swift, den berømte forfatter til Gullivers rejser, udsendte i 1704 The Battle of the Books (Bøgernes kamp). Kampen mellem de gamle og de ny bøger betegner en kulturkamp som rasede i sidste halvdel af 1600-tallet. Udgangen på denne kamp blev fremskridtstankens sejr og oplysningstidens indmarch. De ny må nødvendigvis være bedre end de gamle, for de ny står jo på skulderen af de gamle. Fremskridtet er derfor uundgåeligt. Sådan argumenterede Charles Perrault i slutningen af 1600-tallet. Samme Perrault havde slået sit navn fast som indsamler af folkeeventyr, som han udgav i 1697. Disse eventyr som i århundreder var gået fra mund til mund, blev nu endegyldigt fikseret i den trykte bog, og den mundtlige kultur med dens variationsglæde blev trængt tilbage af skriftkulturens kanoniserede og én gang for alle fastlagte variant. Så behøvede folk jo heller ikke gå og huske på alle disse historier. I dag hedder det: "Hvad du har i 
håndbøgerne, behøver du ikke have i hovedet».

Heraf ses let, som der stod i mine matematikbøger, at bogen er forudsætningen for fremskridtstanken og oplysningstiden, men den er også det middel hvormed de herskende får skabt sig et hukommelsesmonopol. Fra nu af er det staten og dens skriftkloge lakajer, der husker for os, ligesom det er staten der har eneret på at føre krig. Staten har altså eneret på både at bevare og at ødelægge. Til at bevare og forvalte kulturarven konstrueres der vældige hukommelsesmaskiner, først og fremmest bogen og biblioteket.

\section{HYPERTEKST OG DEN LABYRINTISKE ORDEN}

Umberto Ecos elsker at hade biblioteket. Det hænger sammen med hans utopi om et bibliotek uden vægge, og dermed også en bog som ikke længere er lukket, men åben. Det åbne verk er titlen på Eco's måske mest berømte videnskabelige artikel. Den såkaldte hypertekst, som blev opfundet af Ted Nelson i 60'rne, er den nyeste udgave af den åbne bog. Hypertekst vender op og ned på rangordenen mellem hovedtekst og fodnoter, ja faktisk består en hypertekst af lutter fodnoter, som vi kalder frem efter behag og efter behov. $\mathrm{Og}$ hvad mere er, en hypertekst gør det muligt at se forskellige informationer, der stammer fra forskellige steder på disken, at se dem på skærmen på én og samme tid. Det svarer til at læse en bog, hvor man kan se kapitel 1 samtidig med kapitel 3 og kapitel 17. Selvfølgelig har også den elektroniske bog en begyndelse, en midte og en slutning, men ikke nødvendigvis i den rækkefølge.
Computeren, og især hypertekst, er ikke lineær, men flerdimensional. Hypertekster er med til at opløse ideen om at virkelig mening er noget der passer ind i en traditionel, trykt bogs lineære forløb. Men nu skal vi jo ikke glemme at også digtet, det poetiske sprog er et forsøg på at tilbagekalde den linearitet, den éndimensionalitet, som kendetegner hverdagssproget og især de videnskabelige sprog. Til slut i Rosens navn lader Eco hovedpersonen opsøge det nedbrændte bibliotek og ud af asken som en anden fugl Fønix opstår det utopiske bibliotek:

$\mathrm{Da}$ jeg var færdig med min tålmodige rekonstruktion, havde jeg for mig et helt bibliotek, en slags aftegning af det store, som var borte; et bibliotek bestående af brudstykker, citater, ufuldstændige sætninger, amputerede stumper af bøger.

Sådan som fortælleren her til slut sammenstykker sin egen tekst af de mange fragmenter, har læserne heldigvis altid opført sig. Kun de mest autoritære og bedst afrettede har slavisk fulgt den foreskrevne rute gennem bogen. De fleste læsere går deres egne veje. Den list som læserne udviser for at få fat $\mathrm{i}$ forbudte bøger, læse mellem linjerne og omgå den foreskrevne læsemåde, kender ingen grænser. Læseren er en rejsende, som bevæger sig på et fremmed territorium, en nomade som forvilder sig ind på andres jagtmarker. Læsningen er flygtig og springende, mens skriften står fast, bygger op og vil standse tiden. På internettet, ja på billedskærmen, er det at læse det samme som at skrive. Man kan ikke længere skelne mellem de to aktiviteter, som man kan det i bogkulturen, hvor læseren jo helst skal forblive den passive. Mange mennesker 
læser udelukkende bøger for at undgå at skrive.

I den almindelige klagesang over tidernes og sædernes forfald hører man ofte at bogen bliver forsømt til fordel for billedmedierne. Bogkulturens dage er talte, siger man. Men inden man blander sig i koret af kulturpessimister, bør man nok lige overveje om bogen er værd at bevare. De store modstandere af oplysningen har altid haft det svært med bogen. Enten ironiserer de over den som Kierkegaard og skriver bøger som kun består af et efterskrift: Afsluttende, uvidenskabeligt efterskrift. Eller de skriver fragmenter som romantikeren Novalis. I Novalis' Logologiske Fragment fra 1798 kan man læse, at

Tidsskrifter er egentlig allerede fælles bøger. At skrive i fællesskab er et interessant symptom - som lader os ane en betydningsfuld udvikling af forfattervirksomheden. Engang vil man måske skrive en masse - hele forsamlinger, til og med nationer vil arbejde sammen om det samme værk.

Novalis anelser er på vej til at blive virkelighed i dag. Den for tiden mest sejrrige filosofi, dekonstruktionismen, vil netop hævde, at vi alle skriver på den samme tekst. E-mail og Cyberspace og internettet vil gøre fællesteksten til skinbarlig virkelighed.

Når jeg skriver på computeren kan jeg inddrage andres tekster og mine egne tidligere tekster og lade dem smelte sammen med den, jeg er ved at skrive, og jeg kan flytte rundt på tekstblokke $\mathrm{i}$ en håndevending. Det er håndgribelig intertekstualitet, altså tekster der kommunikerer med andre tekster, og det bliver mere og mere meningsløst at spørge: hvem er forfatteren?

\section{BOGENS DØD}

$\mathrm{Nu}$ kan man selvfølgelig gøre sig lystig over, at der for tiden skrives bøger og biblioteker fulde med det budskab, at bogens epoke er slut. Ja, antallet af bøger om bogkulturens død vil en tid lang kunne holde liv i selvsamme bogkultur. Men ved nærmere eftersyn er mange bøger i dag kun bøger i overfladisk forstand. På godt og ondt er det kun limen eller tråden i ryggen, som făr dem til at hænge sammen. Åbner man dem, opdager man at de ikke nødvendigvis er bygget op som bøger tidligere var. De fleste ligner essaysamlinger. Kapitel- og afsnitinddeling, hvis noget sådant overhovedet findes, giver ikke løfte om en fortløbende argumentationsgang eller fortælling, men opfordrer til frem-og tilbagespringende læsning og punktnedslag. Altsammen tyder det på at bogens og skriftens overherredømme er på tilbagetog, og den rationelle tænknings former forbereder sig på en tilbagevenden til en diffus og mangedimensional tænkning.

Schopenhauers, Nietzsches, Wittgensteins skriverier ligner udefra almindelige bøger, men åbner man dem, er de ofte uden egentlig begyndelse og slutning. Det kan være samlinger af aforismer, som måske nok er nummererede, men det er bare for at vi kan finde tilbage til dem. Bogen er her en ren og skær rodekasse, en distributionsform.

Der er mange gode og dårlige grunde til bogens endeligt. Til de dårlige hører, at vi bliver et land af analfabeter, der kan læse og skrive. Blandt de gode hører afmytologiseringen af bogen, den fremadskridende sekularisering, den teknologiske udvikling. Og så det forhold, at markedet for tryksager er overfyldt for tiden. I dag har befolk- 
ningseksplosionen også nået «åndernes rige».

Videnskabelige bøger, det være sig doktorafhandlinger, specialeafhandlinger eller almindelige lærebøger er i dag ofte computerudskrab bygget op efter Lenins tommelfingerregel, at citatet er den korteste afstand mellem to tanker. Men ligegyldigt hvor ringe indholdet i en bog er, nok så mange artikler gør aldrig en bog rangen stridig. Ord $\mathrm{i}$ en bog har nemlig en dobbelthenvisning. De henviser til bogen, som dernæst henviser til virkeligheden. Det sidste er mindre væsentligt. Ord i en bog er altid i godt selskab. Bogen er stadig hellig.

Bogens metafysiske status kan stadig give sig groteske udslag. Lige dele fordomme, banaliteter, trivialiteter og ønsketænkning kan, når denne cocktail rystes sammen til en bog, opnå status af lysende og indlysende sandheder. Man kommer ingen vegne $\mathrm{i}$ det vidensproducerende system, hvis ens viden ikke har antaget bogform. Ikke desto mindre var bogen så at sige født til at blive noget andet og mere end bog.

\section{DE NY ANALFABETER}

De elektroniske multimedier har for længst bevist deres overlegenhed i forhold til bogen. Det bliver også sværere og sværere at fastholde læsningen som en privilegeret tilgang til informationer. Tværtimod er der grund til at antage, at de nye analfabeter bliver dem der kun kan den kunst at afkode den alfabetiske skrift. Den nyligt afdøde kommunikationsfilosof Vílem Flusser mener

at skrive $\mathrm{i}$ den forstand at man kæder bogstaver og andre skriftegn sammen synes overhovedet ikke at have fremtiden for sig. Der er i mellemtiden fremkommet koder, som langt bedre formår at videregive informationer. Det som tidligere blev skrevet kan bedre overføres af lydbånd, grammofonplader, film, videobånd, billedplader eller disketter. Og meget af det som aldrig blev skrevet, kan gengives af disse nye koder.

Næsten hver sommer plejer aviserne at være fulde af artikler og læserbreve som påstår at danske børn ikke længere lærer at læse i skolen, og det til trods for at mange medieforskere i dag gør gældende at det heller ikke er nødvendigt. Med computeren forsynet med de nødvendige multimedieprogrammer kan børn få den kundskab de behøver uden at skulle læse sig til den. De kan endda erhverve skolekundskaberne $\mathrm{i}$ et interaktivt samspil med stoffet. Endelig varer det ikke længe inden computeren selv kan læse teksten højt. Stemmen og skriften, hørelsens og synets verden vil blive koblet sammen, ligesom billedet og stemmen allerede er koblet sammen i videokameraet.

Begrebet analfabet er kun godt hundred år gammelt. Det opfindes samtidig med fonografen, telefonen, lokomotivet og folkeoplysningen. Alle mennesker kan læse, men ikke alle kan læse den erindringsløse, billedløse lineære bogstavskrift. Hver tredie indbygger på vores planet kan ikke læse dens slags tegn. Men de kan læse spillet $\mathrm{i}$ en fodboldkamp, ansigtsudtrykket hos et menneske. Ifølge en kinesisk myte skyldes skriftens opfindelse en højere embedsmand som havde observeret nogle aftryk af fuglespor på en sandet flodbred. Hvis ikke det lige havde været $i$ et vådområde, kunne vi måske her have fundet oprindelsen til udtrykket «kragetæer». "At læse hvad der aldrig blev skrevet", 
8 skriver den tyske filosof Walter Benjamin, «er den ældste form for læsning: læsning før alle sprog.» Den indviede, der læser i stjernerne, i indvoldene, i hænderne, i fuglenes flugt, i dansene, udfører en magisk læsning. Senere kom en ny mere rational læsning til, da vi begyndte at læse runer og hieroglyffer. Og der er mange stationer på vejen frem til vore dages computerskrift: Piktografisk skrift, hieroglyfisk skrift, ideografisk, fonetisk, alfabetisk skrift.

Hans Magnus Enzensberger skrev for ti år siden i en Hyldest til analfabeterne

Når jeg tænker på analfabeten, så forekommer det mig at han egentlig er en respektabel skikkelse. Jeg misunder ham hans hukommelse, hans koncentrationsevne, hans listighed og hans fine øre.

At læse indenad kræver en utrolig selvkontrol. Den der læser indenad underkaster sig teksten. I virkeligheden lærer man slet ikke at læse i skolen, man lærer selvkontrol, og så lærer man at tænke med øjnene og ikke med ørerne. De gamle grækere modtog al lærdom gennem øret og tænkte i og med at de talte. Deres tænkning var dialogisk.

\section{DEN ALFABETISKE FORNUFT VERSUS MYTEN}

Men for at afskaffe det skriftløse menneske, måtte man jo først definere det. Det afføder så også den etnocentriske fordom at der findes såkaldt skriftløse folk. Men det de mangler er jo bare en bestemt type skrift. For da det lykkedes at afkode ikkevestlige skriftarter, blev man klar over at alfabetet, hvad enten det var hebraisk eller græsk, også havde en forhistorie. Det var ikke skabt af Gud, som teologerne hævdede. Alfabetet var ikke begyndelsen.

Det var blot ikke ufarligt at fremføre slige tanker. Universitetsibliotekaren Thomas Bang, som stammede fra Fyn og havde studeret østerlandske sprog ved tyske universiteter og været professor i hebraisk i København, forfattede i 1657 et værk, Coelum Orientis et prisci mundi (Orientens og den gamle verdens himmel), hvori han gik imod den opfattelse at Adam havde opfundet bogstavskriften. Bogen var iøvrigt forsynet med en fire sider lang dedikation til Jesus Kristus. Denne præstation forskaffede Bang en ærefuld plads i Pavens katalog over forbudte bøger - Index Librorum Prohibitorum.

Bogen er på én gang et barn af skriften, og skriftens redskab. Den alfabetiske skrift, der blev opfundet for ca. 5000 år siden, præsterede at underordne det grafiske udtryk under det fonetiske ved at anvende en lineær orden. Med skriften bevægede man sig fra det talte ords tidsmæssige linearitet til en rumlig linearitet, som gør det muligt hele tiden at hente de foregående informationer frem igen. Når skriften ikke er andet end den fonetiske registrering af talestrømmen, når forskellen mellem talt sprog og grafisk udtryk forsvinder, disponerer mennesket over et harmonisk sprogapparat, uden hvilket vi aldrig havde brudt med de mytiske forståelsesformer. At bryde med myten vil informationsteknologisk sige det samme som at opfinde et sprog som ikke længere afbilder den virkelighed, det taler om.

Bogstavskriften, der som bekendt består af 28 billedløse tegn, kan sammenfatte en mangfoldighed af ting ved hjælp af få tegn. Ordet hus kan betegne alle eksisterende og forestillede huse i verden. Prisen 
for denne forenkling er at sproget taber verden af syne. Verden bliver en sproglig konstruktion. Herfra er der ikke langt til at opfatte verden som en opslået bog. Fra middelalderen stammer udtrykket «naturens store bog", og i renæssancen er det at udforske naturen det samme som at læse i naturens bog. Galilei mente ligefrem at verden var skrevet i matematikkens sprog.

Den vesterlandske fornuftskultur er karakteriseret ved, at alt skal følge af noget andet og derfor også kunne føres tilbage til noget tidligere, som dets grund. Grund og følge, begrundelse og konsekvens er hovedhjørnestenene i en rationalitet, som er opstået på grundlag af det alfabetiske systems linearitet. Men vi ved jo at der har eksisteret og stadig eksisterer ikke-lineære skriftformer.

\section{EKSKURS OM MCLUHAN}

Den canadiske medieguru Marshall McLuhan, som døde nytårsnat 1981, var mindst et kvart århundrede forud for sin tid. Hans feltråb, at mediet er budskabet, blev vendt mod ham selv. Den gennemslagskraft hans teorier fik i starten blev bortforklaret med den udstråling, som udgik fra hans person, og fra den associative logik og montageagtige form, som udmærkede hans skrifter. Man anklagede ham for udelukkende at ville chokere og vække opsigt. Læs eksempelvis Villy Sørensens hånlige anmeldelse af Mennesket og Medierne under overskriften "Mc Luhans glædelige budskab" (optrykt i Mellem Fortid og Fremtid)! Hans muntre videnskab blev beskyldt for at tilsidesætte sandheden til fordel for budskabets medieeffekt. Selv kaldte han sig i et brev til Ezra Pound for en «intellektuel gangster, som lidt efter lidt har opbygget et privat våbenlager». Man gjorde alt for at latterliggøre ham og kaldte hans filosofi "Summa Popologica» med en slet skjult henvisning til Thomas Acquinos Summa Theologice.

I 70'rne forsvandt McLuhan fra scenen, jaget ud af de bogdyrkere, som CDROM'en nu omsider făr lagt i graven. Men i dag er McLuhan tilbage og med til at bære bogkulturen til graven. Firsernes franske medieguruer, Jean Baudrillard og Paul Virilio, indrømmer deres gæld til ham. Sidste år udsendte den tyske mediefilosof Norbert Bolz en bog om de nye computermedier med titlen Ved Gutenberg galaksens afslutning. Ved i selve titlen at citere McLuhans berømte bog fra 1962, The Gutenberg Galaxy, skaffer han på smukkeste vis profeten oprejsning.

Det er den teknologiske udnyttelse af elektriciteten, som har medført en revolution i kommunikations-, perceptions- og tankeformerne. De elektroniske medier er forlængelser af vort nervesystem. De har fàet kloden til at trække sig sammen og forvandlet den til en global landsby. Elektriciteten har ophævet tid og rum som kommunikationsbarrierer og forvandlet eksplosion til implosion.

«I don't explain, I explore», skrev McLuhan i Understanding Media (1964, da. udg. 1967). Men allerede i The Gutenberg Galaxy proklamerede han at "videnskabens opgave er ikke at finde frem til et synspunkt, men at opdage, hvordan man kan undgå at indtage et synspunkt», eller i det mindste indtage mange synspunkter samtidig.

Indsigter er ikke det samme som synspunkter. Jeg har ikke et eneste synspunkt på noget som helst. Jeg 
10 er interesseret $\mathrm{i}$ modaliteter og processer. Du antager jeg har et synspunkt; ikke sært at jeg virker arrogant!

Den ny fornuft, informationsteknologifornuften (IT-fornuften), famler sig frem som i blinde, som en opdagelsesrejsende i ukendt land.

Samlermennesket dukker op igen, men nu som informationssamler. I denne rolle er det elektroniske menneske en nomade i lige så høj grad som sine palæolitiske forfædre.

Også nomadens mytiske verdensopfattelse vil få en renæssance.

Tilværelsen er for mangfoldig og foranderlig til at den kan sættes på en fællesnævner, tvinges ind under den samme forståelsesform eller fremstilles som rene kausalforhold. Udforskningens metode, den eksplorative metode, sonderingen, fremsætter hverken slutninger eller hypoteser, men "probes». McLuhan citerer gerne Bertrand Russell, som mente at århundredets største opdagelse var «den udsatte afgørelses metode». Forfatteren afstår fra at drage en slutning, men nøjes med at tilrettelægge et stimulerende materiale. Han formulerer "sonder», som læserne kan håndtere. Ikke pakker som de enten kan tage imod eller afvise.

McLuhan er fortaler for alternative standards for tænkning og fremstilling. Han vil udvikle former for fornuft og fremstilling som først giver mening i lyset af en anden sensibilitet end det moderne Vestens ensidigt visuelle. Den orden som råder i hans tekster ligner den slags hånden støder på, når den famler sig frem, og ikke den slags som viser sig for øjet når det præsterer det olympiske overblik eller tilbageblik:
Den civiliserede fornuft forventer og foretrækker, at problemet bliver beskrevet og analyseret sekventielt. [---]

Sonderingens metode begynder med at indrømme uvidenhed og usikkerhed, og famler sig forsøgsvis frem. For den blindes stok afslører forholdet mellem ting $\mathrm{i}$ omgivelserne sig som resonans. Berøring med stokken giver varsel om ting som befinder sig i nærheden. Hvis stokken var forbundet med nogen af disse ting, ville den blinde være helt ude af stand til at orientere sig. Således er den logiske metode. Når det gælder sondering, er den helt ubrugelig.

Når man vil meddele sine sonderinger, begynder man med virkningen på læseren. At skrive er ikke at overbringe et budskab, man sidder inde med, men at udvikle et formbegreb, idet man søger at foregribe en effekt. Man skal skrive med læsningens effekter for øje og således inddrage læseren som medforfatter. Teksten er en figur og læseren er den baggrund, den står frem på. "My consumers are they not my producers» (skriver Joyce i Finnegans Wake). Rollen som suverænt skabende eller erkendende subjekt er passé. Det handler altså ikke så meget om at gengive et stykke virkelighed som om at finde et uobjektivt korrelat", et "mot juste" - den rammende formulering, som engagerer læseren således at han danner sig et bestemt indtryk af virkeligheden og indtager en bestemt holdning til den.

Når et område undersøges på famlende vis, fremstår det som mosaik. Det består af mange forskellige stykker, og hver stykke har en bestemt farve. Tilsammen danner de et mønster. Mosaikken er diskontinuerlig, uregelmæssig, ikke-lineær. Den udnytter intervallet, ikke sammenføjningen, og intervallet, spillerummet, tillader at der 
springer gnister mellem kontrasterne. Hvis fortællingen og argumentationen er «eksplosive» former, er mosaikken «implosiv». Den mangler impulser til fremdrift og ekspansion, men virker ved sammentrækning og fortætning. Allerede The Gutenberg Galaxy opviser denne struktur med dens 107 små kapitler, som alle tjener som en slags anekdote, en lille verden for sig. De skal ikke læses i en bestemt rækkefølge, men gribes som en mosaik i deres mangfoldige udvekslinger. Mosaikformen gør sig ikke bare gældende i kompositionen, men også i stilen, som er diskontinuerlig og aforistisk. Stil er her ikke bare udvendig pynt, for "Enhver stil er en måde at erkende på».

I stedet for Gutenberg-Galaksens linexre rationalitet får vi en tænkning i konfigurationer, i stedet for den klassiske sandhedsteori får vi et konstruktivistisk kriterium for det "passende", kausalitet erstattes af rekursion, klassifikation af mønstergenkendelse, at forstå vil sige at simulere. $\mathrm{Og}$ virkeligheden bliver en operationel sammenhæng.

\section{BENJAMIN OG FORNYELSEN AF SPROGET}

Walter Benjamin drømte om en radikal fornyelse af sproget, hvorved det rationelle, diskursive sprog får tilført den fortryllende, forføreriske og magiske kraft som sproget havde før det blev billedløst og verdensløst. Med et sådant sprog vil den logisk, diskursive tænkning blive fortrængt af en associativ tænkning. Diskursiv betyder egentlig «løbende tale», dvs. en lineær tænkning à la: når man har sagt $\mathrm{A}$, må man også sige $\mathrm{B}$ i kærlighedens $\mathrm{ABC}$. Den associative tænkning er springende. Den spørger ikke: hvad kommer af hvad, men hvad korresponderer med hvad.

Reminiscenser af denne magiske kraft i sproget har overlevet i navnet, og ikke mindst i øgenavnet. Og Benjamin ventede denne fornyelse af informationsteknologien. Og han behøvede ikke at vente længe, for miraklet var jo allerede sket. Skriften havde forladt bogen. Den havde rejst sig fra sit sygeleje. I dag er der skrift overalt. Som græshoppesværme slår skriften ned over byerne og sidder nu på husgavle, facader, trøjer, biler, tog etc. Megen skrift, især varenavne, virker overbevisende ved deres blotte nærvær. Endelig suser skrifttegnene herreløse rundt i de elektroniske kredsløb.

Walter Benjamin formulerede sine tanker om skriftens historie engang i trediverne og skriver, at

skriften oprindeligt stod op, hugget ind i klippevæggen, ridset ind $\mathrm{i}$ runestenen, skåret ind $\mathrm{i}$ træet. Men så begyndte den at lægge sig ned. Først blev den til den på pulten hvilende håndskrift, for så til sidst at finde til sengs i bogtrykket. Men nu begynder den langsomt igen at rejse sig fra gulvet. Allerede avisen bliver læst mere lodret end horisontalt, film og reklamer tvinger fuldstændigt skriften ind $\mathrm{i}$ den diktatoriske vertikal. Og førend mennesket af i dag når at slå en bog op, er der faldet en så tæt regn af omskiftelige, farvede, indbyrdes stridende bogstaver ned for hans øjne, at der nu er ringe chance for at han kan trænge ind $\mathrm{i}$ bogens arkaiske stilhed. Græshoppesværme af skrift formørker allerede i dag solen for storbyboens formodede ånd, og de vil blive tættere år for år. Skriftens udvikling bliver ikke ved med at være underkastet magtkravene fra en kaotisk videnskab og reklame, tværtimod vil det øjeblik komme, hvor kvantitet slår om i kvalitet, hvor skriften, som trænger stadig mere ind i sin nye excentriske billedligheds grafiske område, med 
12 ét slag får fat på sit adækvate indhold. Med denne nye tekniske billedskrift vil de nye skriftkloge opnå en autoritet $\mathrm{i}$ de folkelige lag i sammenligning med hvilken enhver aspiration om at forny retorikken vil tage sig ud som gammeldags drømmeri. (Ensrettet gade, 1993)

Den billedkvalitet skriftsproget har fået i den såkaldt kulørte presse, i reklamen og i de mest avancerede poetiske tekster, $\mathrm{fx}_{\mathrm{i}}$ futurismens tekster, får det i dag i computeren. Datakompressionen i computeren betyder at tekster behandles som billeder. Vi klipper, klistrer og kopierer. Og har man tilstrækkelig computerkraft kan billeder behandles som tekst, idet de kan brydes ned og sammensættes på ny. På en måde var det jo det, impressionisterne gjorde. De opløste genstandene i farvepletter, linjer, lys og atmosfære og genopbyggede så genstandene af dette grundmateriale, disse nøgne sansedata. Den gamle skelnen mellem tekst og billede er blevet uholdbar, og det hænger sammen med digitaliseringen af alle former for data. I grunden findes der ikke længere nogen forskel på lyd, billede og ord. Et nyt digitalt alfabet ligger til grund for dem alle.

Teksten er oprindelig et foredrag på Museet for samtidskunst i Oslo den 10. april 1997 i forbindelse med konferencen "Art and Technology».

\section{SUMMARY}

With Gutenberg on Internet

The paper comments on the development of verbal communication from orality, through written and printed text up to the age of the computer. The importance of Marshall McLuhan is underlined for his insistence on the potential new freedom from the rigid linearity of the text which modern media have offered. It is argued that the computer with its capacity for editing and linking and its use of hypertext offers us the means for a new way of expressing our thinking, envisioned by Mc Luhan. A way, better adapted to the complexity both of the reality we try to grasp and master intellectually with words and the patterns of thinking we actually use in that process. The author points to writers such as Schopenhauer, Nietzsche and Wittenstein as forerunners. They keep adding observations and reflections together in short notes rather than in a discursive text in order to adequately describetheir impressions of a constantly shifting and changing reality. Are they foretelling the death of the book, the enlightenment culture of the rational argument? No doubt they have influenced postmodern thinking. To underpin the analysis references are made to Umberto Eco and Walter Benjamin, as well as to Vílem Flusser, who stated that the 20th century has produced codes for the transfer of information such as films, sound- and videotapes, disks and CDROMs which are superior to the written word. The new media when combined in various ways can thus communicate a multidimensional, multisensory message more efficiently than any text.

Arno Victor Nielsen er Mag.art. et cand. mag. i filosofi og litteratur, medarbejder ved Danmarks Radio, professor $i$ kunstfagenes teori ved Kunsthogskolen $i$ Bergen.

Adr. H/F Kalvebod 79, DK-2450 Kobenhaun SV 